\title{
41. REGIONAL SYNTHESIS OF THE DEEP SEA DRILLING RESULTS FROM LEG 22 IN THE EASTERN INDIAN OCEAN
}

\author{
John G. Sclater, ${ }^{1}$ Chris von der Borch, ${ }^{2}$ John J. Veevers, ${ }^{3}$ Roger Hekinian, ${ }^{4}$ Robert W. Thompson, ${ }^{5}$ \\ Anthony C. Pimm, ${ }^{1}$ Brian McGowran, ${ }^{6}$ Stefan Gartner, Jr., ${ }^{7}$ and David A. Johnson ${ }^{8}$
}

\section{INTRODUCTION}

The eastern Indian Ocean is bounded to the north by the Indian continent and the Sunda Trench, to the east by Australia, and to the south and west by the active southeast and central Indian ridges, respectively. The ocean is dominated by three long linear topographic features-the Chagos-Laccadive Plateau which separates the Central Indian Basin from the central Indian Ridge, the Ninetyeast Ridge which separates this basin from the Wharton Basin, and Broken Ridge which forms the southern boundary of the Wharton Basin. The Ninetyeast Ridge is by far the longest and most impressive feature, running almost due south along the $90^{\circ} \mathrm{E}$ line of longitude from the Nicobar Islands at $15^{\circ} \mathrm{N}$ to the western extension of Broken Ridge at $31^{\circ} \mathrm{S}$. For most of its length the Ninetyeast Ridge has an elevation of 1500 to 2000 meters above that of the surrounding ocean floor.

The Ninetyeast Ridge was recognized as a major topographic feature by Sewell (1925) who named it Carpenter's Ridge. It was first delineated as a long north-south feature on the topographic chart of Stocks (1960) and the Russian Atlas of the Indian Ocean (Anon, 1964). It was given its present name by Heezen and Tharp (1965). Originally, it was thought that this ridge and the parallel but shorter and similarly aseismic Chagos-Laccadive Plateau were topographic scars left behind as India moved northward after the breakup of Gondwanaland.

Distinctive magnetic anomaly patterns have been recognized in almost all the major basins of the Indian Ocean. Matthews (1966) and Fisher et al. (1970), recognized magnetic lineations in the Arabian Sea and northeast Somali Basin, respectively. McKenzie and Sclater (1971) identified these anomalies. Fisher et al. (1971) found younger anomalies associated with the central Indian Ridge and lying between the Mascarene Plateau and the Chagos-Laccadive Plateau. Using the identifications of the anomalies in the Arabian Sea and Somali Basin, these authors suggested that these two plateaus were once joined and marked a major offset of the magnetic anomalies in

\footnotetext{
${ }^{1}$ Scripps Institution of Oceanography, La Jolla, California.

${ }^{2}$ Flinders University, Bedford Park, South Australia.

${ }^{3}$ Macquarie University, North Ryde, N.S.W., Australia.

${ }^{4}$ Centre Oceanologique de Bretagne, Brest, France.

${ }^{5}$ Humboldt State College, Arcata, California.

${ }^{6}$ University of Adelaide, Adelaide, South Australia.

${ }^{7}$ Rosentiel School of Marine and Atmospheric Science, University of Miami, Coral Gables, Florida.

${ }^{8}$ Woods Hole Oceanographic Institution, Woods Hole, Massachusetts.
}

pre-Eocene time. They named this ancient transform fault the Chagos Fracture Zone and suggested that during the Late Cretaceous and early Tertiary it marked the relative motion of the Indian plate relative to the African plate. The overall similarity of the present Ninetyeast Ridge to the Chagos Fracture Zone in the Eocene (cf. Fig. 42 of McKenzie and Sclater, 1971) is strong evidence for a similar tectonic origin.

Various authors have suggested an alternative mode of formation for the Ninetyeast Ridge. Francis and Raitt (1967), on the basis of the sharp eastern scarp and a thin oceanic-type crust, suggested it was a hörst-type feature. LePichon and Heirtzler (1968) postulated that the compressional forces necessary to produce uplift could have occurred by relative motion between the Indian and Australian plates. McKenzie and Sclater (1971) argued that this motion could have resulted in the Eocene when the southeast Indian Ridge changed spreading direction from dominantly north-south to northeast-southwest. However, Bowin (1973) has shown that the free air gravity anomaly over the ridge observed by LePichon and Talwani (1969) and himself is too small by almost 100 mgals for the ridge to be a simple hörst-type feature. Thus, though the tectonic setting of the ridge is understood, the reason for its existence as a topographic elevation is unknown.

McKenzie and Sclater (1971) and Sclater and Fisher (in press) have recognized distinctive magnetic anomalies in the Central Indian Basin (Figure 1). They have recognized anomalies 5 through 16 and 21 through the beginning of 33 spreading north at $2.5 \mathrm{~cm} / \mathrm{yr}(5-16), 4.0 \mathrm{~cm} / \mathrm{yr}(16-22), 8.0$ $\mathrm{cm} / \mathrm{yr}(22-27), 12.0 \mathrm{~cm} / \mathrm{yr}(27-29)$, and $5.7 \mathrm{~cm} / \mathrm{yr}(29-33)$, respectively. The anomalies cannot be traced over long distances east west and as a consequence, these authors have suggested that the Central Indian Basin is made up of a series of short east-west segments offset by north-southtrending fracture zones at $79^{\circ} \mathrm{E}$ (Indrani), $83^{\circ}$ (Indira), and $86^{\circ} \mathrm{E}$.

To the east of the Ninetyeast Ridge and south of Broken Ridge McKenzie and Sclater (1971) and Weissel and Hayes (1972) found symmetrical anomalies which range in age from the Eocene to the present. On the basis of the identifications, these authors have argued that Australia and Antarctica were once joined and separated in the middle Eocene. To the north in the Wharton Basin, Vacquier and Taylor (1966) and LePichon and Heirtzler (1968) recognized distinctive east-west-trending anomalies which they were unable to identify. Sclater and Fisher (in press) have identified these and other anomalies in the western half of the Wharton Basin. They have shown that this portion of the basin was formed by an east-west-trending ridge spreading south between the time of anomalies 19 and 


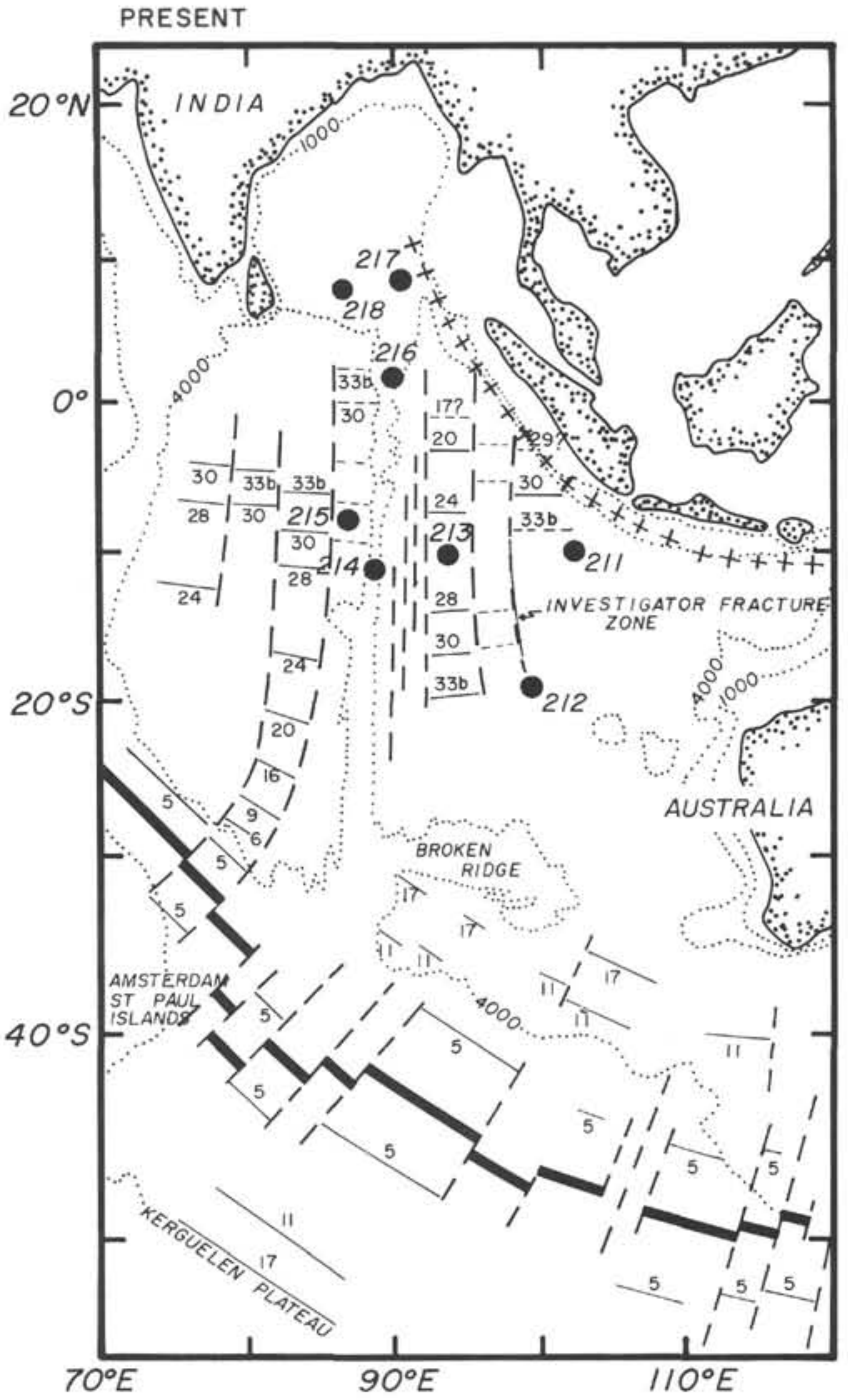

Figure 1. Sites from Leg 22 superimposed upon the tectonic chart of the eastern Indian Ocean from Sclater and Fisher (in press). The dashed lines represent fracture zones and the numbers indicate identified magnetic anomalies.

33 at rates of $4.0 \mathrm{~cm} / \mathrm{yr}(19-22), 8.0 \mathrm{~cm} / \mathrm{yr}(22-27), 13.1$ $\mathrm{cm} / \mathrm{yr}(27-29)$, and $6.0 \mathrm{~cm} / \mathrm{yr}$ (29-33), respectively. Thus, spreading in the Wharton Basin was almost identical in rate but opposite in direction to that in the Central Indian Basin between the time of anomalies 19 and beginning of 33 (middle Eocene to Late Cretaceous). During this time span the Ninetyeast Ridge was a transform fault and marked the relative motion between the Indian and Australian plates.

Like the Central Indian Basin, the magnetic lineations of the Wharton Basin cannot be traced far in an east-west direction. Sclater and Fisher (in press) have postulated that the basin also is made up of a series of short east-west sections cut at $96^{\circ} \mathrm{E}$ and $98^{\circ} \mathrm{E}$ by two north-south transform faults offsetting crust of the same age left laterally to the north. The $98^{\circ} \mathrm{E}$ offset shows up as a striking north-south topographic feature, less than $50 \mathrm{~km}$ wide some 1000 to 1500 meters high, which Sclater and
Fisher (in press) named the Investigator Ridge. This feature terminates to the north in the Sunda Trench.

Between $93^{\circ} \mathrm{E}$ and the Ninetyeast Ridge, the Wharton Basin is cut by a series of long north-south deeps and shaols. The most prominent of these is a spectacular deep just to the east of the Ninetyeast Ridge. Sclater and Fisher (in press) and Bowin (1973) have suggested that this deep may be the remnant of the old transform fault and that the Ninetyeast Ridge may be a secondary feature attached to the Indian plate.

The absence of identifiable magnetic anomalies has led to much speculation concerning the age and origin of the Wharton Basin. Dietz and Holden (1971), on the basis of a gap between India and Australia in the computer best fit of the Gondwana continents of Smith and Hallam (1970), suggested that the basin is pre-Mesozoic. However, Veevers et al (1971) have argued that the non-marine Jurassic sedimentary sequences in western Australia are evidence that western Australia was land bounded at least until the Early Cretaceous. They extended their arguments to the ocean floor and postulated that the Wharton Basin was no older than Cretaceous. This younger age has received strong observational support from the identification of anomalies 19 through 33 in the western half of the basin. However, the anomalies recognized by Falvey (1972) off northwest Australia remain unidentified.

The eastern Indian Ocean can be separated into five distinct sedimentary provinces. The Central Indian Basin stretches north from the southeast Indian Ridge at $40^{\circ} \mathrm{S}$ to the distal end of the Bengal Fan at $10^{\circ} \mathrm{S}$. The sediments are thin and predominantly pelagic (Ewing et al., 1969). The Bengal Fan sediments are predominantly terrigenous and become increasingly so approaching their source at the Swatch of No Ground just south of the Brahamaputra River (Curray and Moore, 1971). The Ninetyeast Ridge is thought to be capped by calcareous pelagic sediments throughout its length. To the east of this ridge the Nicobar Fan is the easterly extension of the Bengal Fan, and the sediments are almost all terrigenous. South of this fan lies the Wharton Basin which only has a very thin cover of pelagic sediments (Ewing et al., 1969).

In this chapter a regional summary of the data gathered from the holes drilled on Leg 22 is presented. For convenience the results from holes drilled in the Wharton Basin, the data from the sites on and on either side of the Ninetyeast Ridge, and the results from drilling on the Bengal fan are discussed separately. Finally, the implications of this synthesis for the tectonic history of the Indian Ocean are discussed.

\section{MAJOR OBJECTIVES AND PRINCIPAL RESULTS FROM LEG 22}

In view of the large distance to be traveled, it was decided at the beginning of Leg 22 to drill no more than eight holes and to concentrate on coring as much of the section as possible. Three holes were drilled in the Wharton Basin $(211,212$, and 213) three on the Ninetyeast Ridge $(214,216$, and 217), one in the central Indian Basin (215), and the last in the Bengal Fan (218) (Figure 2). 


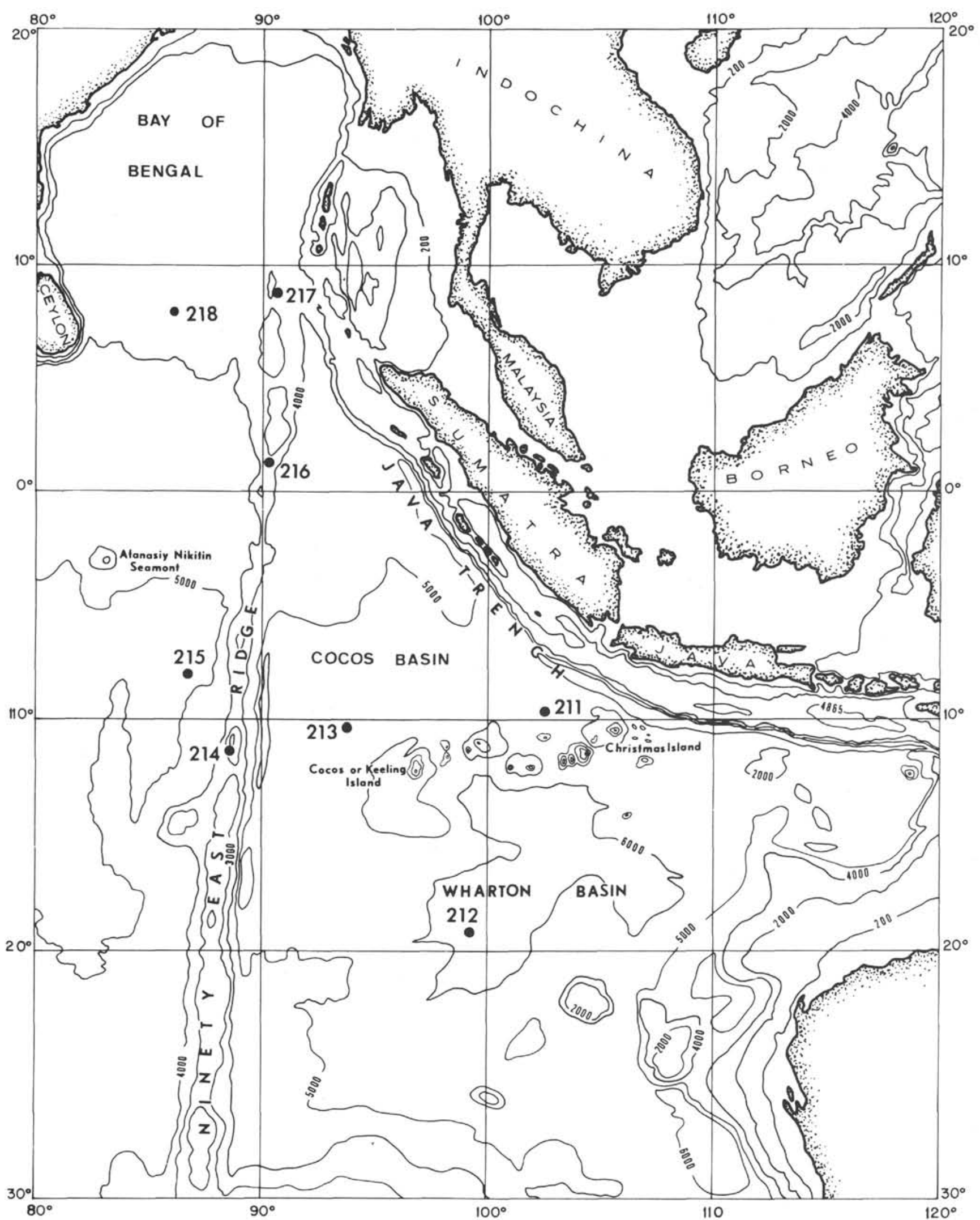

Figure 2. Sites from Leg 22 superimposed upon the topographic chart of the eastern Indian Ocean from the new Russian Atlas (Udinstev, personal communication). 
The first three sites were chosen to investigate the sedimentary structure and age of the Wharton Basin. At Site 211 the acoustically transparent sediments were sampled south of the Sunda Trench and the age of the north central portion of the basin was also determined. Site 212 was drilled in a deep sediment-filled trough near the center of the basin. This was the deepest hole on record in the DSDP program with 6,750 meters of pipe out when meta-basalt was cored. This site was picked because it was believed that the deepest portion of the basin would also probably be the oldest. Site 213 , some $4^{\circ}$ east of the Ninetyeast Ridge, was selected to check the preliminary (at that time) identification of anomaly 26 at this location by Sclater and Fisher (in press). A good sediment basement contact was obtained, and the biostratigraphic age was 5-9 m.y. younger than the predicted magnetic age.

Five sites were drilled on and on either side of the Ninetyeast Ridge (213, 214, 215, 216, and 217). Site 214, on the Ninetyeast Ridge, gave almost exactly the same age as Site 215 in the central Indian Basin to the west. This strengthened the hypothesis that the Ninetyeast Ridge has always been attached to the Indian plate. Two additional sites (216 and 217) were selected on the Ninetyeast Ridge, with two principle objectives: the first to determine the mode of origin of the Ninetyeast Ridge, the second to examine the northward motion of the Indian plate during the Late Cretaceous and early Tertiary. Site 217 had the additional objective of attempting to sample Bengal Fan turbidities which were postulated to have spilled onto the northern section of the ridge prior to its uplift (Curray and Moore, 1971). Site 218 was picked to date unconformities in the Bengal Fan which were believed to reflect uplift in the Himalayas.

The position of the sites, the lithologic log, and the principal results are summarized in Figures 2 and 3 and Table 1 . The most striking results are the relative youth of the Wharton Basin (no older than Cretaceous), the discovery of lignite at Site 214 , and a very shallow environment for sediments at the base of all three sites on the Ninetyeast Ridge. In terms of tectonic reconstructions, perhaps the most important discovery was that the Ninetyeast Ridge, which is the western remnant of a transform fault, has always been attached to the Indian plate. This single factor allows, under certain simple assumptions, a major advance in our understanding of the relative positions of India, Australia, and Antarctica in the Late Cretaceous.

Two reliable heat flow values were obtained on the Ninetyeast Ridge. Both were close to normal for the age of the crust beneath and were within the standard deviation of nearby conventional measurements (Sclater and Erickson, Chapter 14).

Absolute age dates from biostratigraphic information referred to in the following discussion are taken directly from the biostratigraphic time scale of Pimm and Hayes (1972) for the pre-Tertiary and Berggren (1972) for the Tertiary (Figure 4a). The absolute age dates of the magnetic anomalies are taken from the modification by Sclater et al. (Chapter 13) of the Heirtzler et al. (1968) time scale (Figure 4b).

\section{WHARTON BASIN SITES}

Site 211 lies $2.5^{\circ}$ south of 33 and had a sediment basement contact age of Campanian ( 72 to 80 m.y.B.P. on the Cretaceous time scale of Pimm and Hayes, 1972, Table 1). Assuming an average age of 76 m.y.B.P. for the crust at Site 211 , this is 5 m.y. older than the crust at the beginning of anomaly 33 to the north (71 m.y.B.P. on the time scale in Figure $4 \mathrm{~b}$ and Chapter 13, Figs. 1 and 2. Thus, the drilling data are consistent with the magnetic identifications to the north and are strong but not positive evidence that the $6 \mathrm{~cm} / \mathrm{yr}$ spreading rate of the older anomalies (29 through beginning of 33) continued further back in time.

The Investigator Fracture Zone, a long linear topographic high running from the Sunda Trench at $98^{\circ} \mathrm{E}$ to $19^{\circ} \mathrm{S}, 100^{\circ} \mathrm{E}$, bisects the north central Wharton Basin (Figure 1). Site 212, which was drilled in the deepest portion of the basin, lies in a pronounced sediment filled deep at the southern extremity of this fracture zone. Although the basement contact is a 30-meter section of brown clay, an estimate of the age of the oceanic crust was made using average accumulation rates of clay higher in the section. The inferred age is close to the Late/Early Cretaceous boundary. However, the basement is definitely no younger than Cretaceous. We consider this confirmatory evidence of the young age for the Wharton Basin.

Site 213 was drilled on the younger (northern) side of anomaly 26 and obtained an excellent sediment basement contact. The basal sediments which had to be removed ultrasonically from the pillow basalts gave an age of 56 to 58 m.y.B.P. which is 5-9 m.y. younger than that given for the basement by the magnetic time scale of Heirtzler et al. (1968). This difference is significant and has led to the assigning of younger ages to the magnetic anomalies older than anomaly 5 . This difference and a new magnetic time scale are discussed at some length in Chapter 13. The age of the basement sediments at Site 213 is compatible with the identification of the early Cenozoic magnetic anomalies in the region.

Other important discoveries resulted from the drilling in the Wharton Basin. Site 212 has been subjected to several major phases of rapid carbonate deposition below the carbonate compensation depth. Each phase is separated by deep-sea brown clay. The carbonate sediments are reworked from shallower water and were apparently emplaced rapidly since they are restricted to very narrow time intervals. The peculiar stratigraphy is probably related to the location of the site in a deep gash at the southern extremity of the Investigator Fracture Zone. Unlike Site 212, which may have always been below the carbonate compensation depth, Sites 211 and 213 show a history of subsidence with a basal calcareous sequence grading up into deep-water brown clays (Pimm, Chapter 39). All three sites show some degree of iron enrichment (Pimm, Chapter 20) in the lower sections. The uppermost sediments at these sites are upper Tertiary siliceous oozes which have been deposited beneath the Indian Ocean zone of high productivity. A substantial accumulation of turbidites, representing part of the Nicobar Fan, occurred at Site 211 during the Pliocene. This activity terminated in the upper Pliocene at the same time as the 

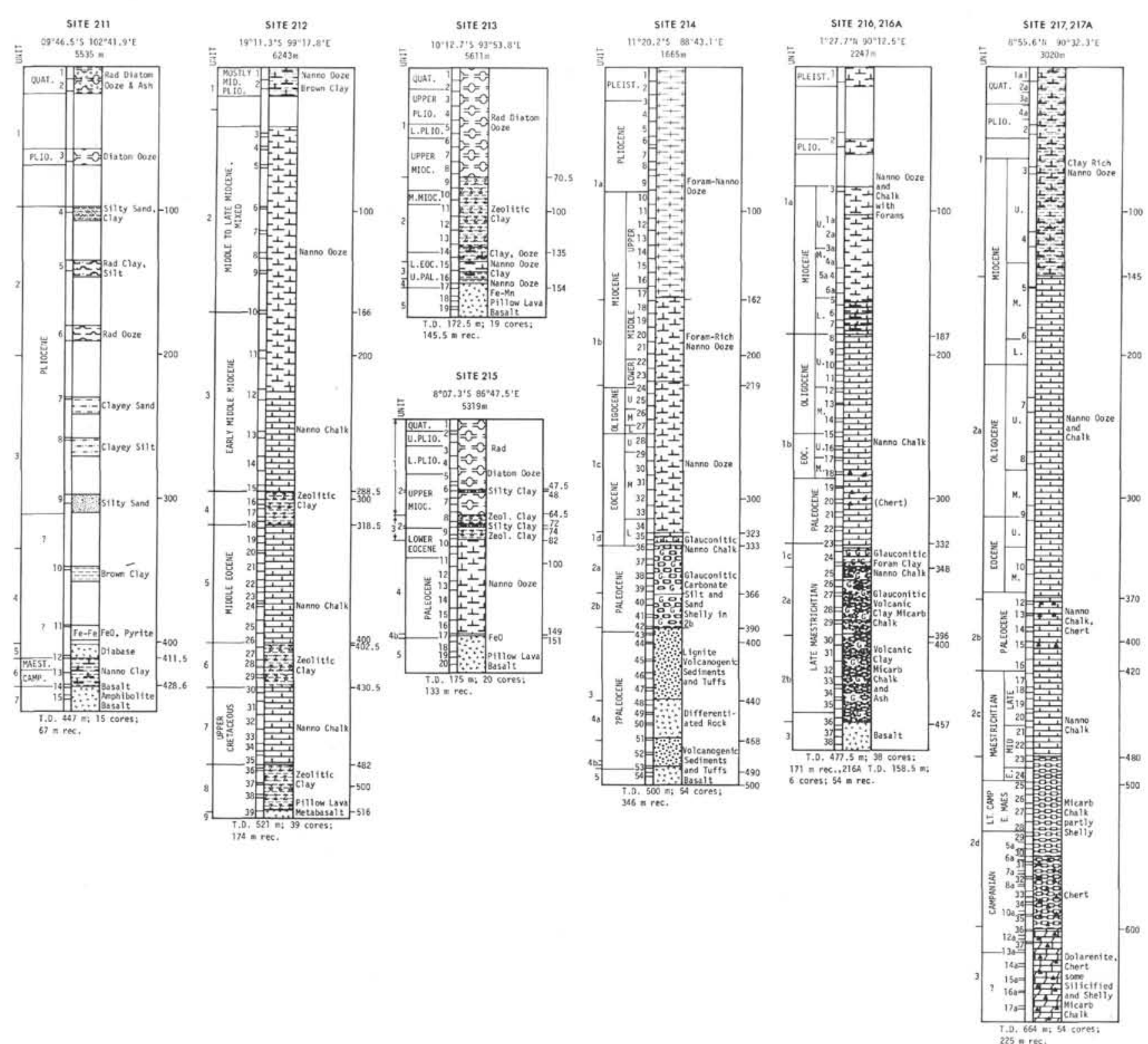
TABLE 1

Principal Results of Leg 22

\begin{tabular}{|c|c|c|c|c|c|c|c|c|c|c|}
\hline Site & Latitude & Longitude & $\begin{array}{l}\text { Depth } \\
\text { Drill } \\
\text { Pipe } \\
\text { (m) }\end{array}$ & $\begin{array}{l}\text { Nannofossil } \\
\text { Age }\end{array}$ & $\begin{array}{c}\text { Foraminifera } \\
\text { Age }\end{array}$ & $\begin{array}{c}\text { Hard } \\
\text { Rock } \\
\text { Age }^{\mathrm{a}}\end{array}$ & $\begin{array}{l}\text { Magnetic } \\
\text { Age }^{\mathrm{b}}\end{array}$ & $\begin{array}{c}\text { Anomaly } \\
\text { Age } \\
\text { (Adjusted) }\end{array}$ & Igneous Rocks & Principal Results \\
\hline 211 & $9^{\circ} 46.53^{\prime} \mathrm{S}$ & $102^{\circ} 41.95^{\prime} \mathrm{E}$ & 5535 & $72-75$ & $\begin{array}{l}\text { Late } \\
\text { Cretaceous }\end{array}$ & $\begin{array}{l}71,73 \\
69,69\end{array}$ & $\begin{array}{l}\sim 80 \text { or } \\
\text { greater }\end{array}$ & 74 & $\begin{array}{l}\text { Diabase sill, then } \\
17 \mathrm{~m} \text { of sediment } \\
\text { above a basalt with } \\
\text { amphibolite. }\end{array}$ & 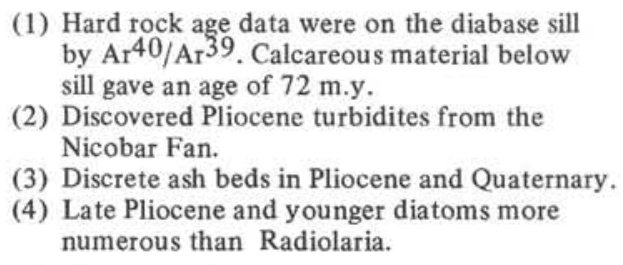 \\
\hline 212 & $19^{\circ} 11.34^{\prime} \mathrm{S}$ & $99^{\circ} 17.84^{\prime} \mathrm{E}$ & 6243 & $65-67^{*}$ & $\begin{array}{l}\text { Late } \\
\text { Cretaceous }\end{array}$ & & $\begin{array}{l}\text { No estimate } \\
\text { Too close to } \\
\text { a fracture } \\
\text { zone }\end{array}$ & & $\begin{array}{l}\text { Pillow lava } \\
\text { metabasalt }\end{array}$ & $\begin{array}{l}\text { (1) } 34 \text { meters of brown clay above basement. } \\
\text { Assuming the same rate of sedimentation for } \\
\text { the brown clay units above gives } 91 \mathrm{~m} . \mathrm{y} \text {. } \\
\text { with a spread of } 80 \text { to } 110 \mathrm{~m} . \mathrm{y} \text {. } \\
\text { (2) } 5 \text { displaced carbonate units below the com- } \\
\text { pensation depth. } \\
\text { (3) High iron content in the basal sediments. } \\
\text { (4) Paleomagnetic measurements on brown clay } \\
\text { (Unit } 5,402-430 \mathrm{~m} \text { ) shows } 12^{\circ} \text { northward } \\
\text { shift since the Late Cretaceous. }\end{array}$ \\
\hline 213 & $10^{\circ} 12: 71 ' \mathrm{~S}$ & $93^{\circ} 53.77^{\prime} \mathrm{E}$ & 5611 & $55-57$ & $\leqslant 58$ & & $\begin{array}{l}63-65 \\
\text { Beginning of } \\
\text { anomaly } 26\end{array}$ & 59 & $\begin{array}{l}\text { Weathered pillow } \\
\text { basalt }\end{array}$ & $\begin{array}{l}\text { (1) Dated the beginning of anomaly } 26 \text { with } \\
\text { trapped calcareous fossils between the lava } \\
\text { pillows. } \\
\text { (2) High iron content in basal brown clays. } \\
\text { (3) A brown clay section within core } 11 \text { spans } \\
\text { middle Eocene to middle Miocene. } \\
\text { (4) Transition from calcareous to noncalcareous } \\
\text { sediments occurs in the lowermost Eocene. } \\
\text { (5) Three ash beds in upper Miocene to Quater- } \\
\text { nary sediments. } \\
\text { (6) Diatoms more abundant than Radiolaria in } \\
\text { upper Miocene to Quaternary. }\end{array}$ \\
\hline 214 & $11^{\circ} 20.21^{\prime} \mathrm{S}$ & $88^{\circ} 43.08^{\prime} \mathrm{E}$ & 1665 & $\begin{array}{l}57-61 \\
\text { (Core 37) } \\
57-61 \\
(41, C C)\end{array}$ & $\begin{array}{l}56-58 \\
\text { (Core 37) }\end{array}$ & $\begin{array}{l}53.9 \\
52.9 \\
\text { (Core 48) }\end{array}$ & & & $\begin{array}{l}\text { Differentiated } \\
\text { rocks (Cores 48-51) } \\
\text { above tuffs } \\
\text { above (Cores 51-53) } \\
\text { oceanic island } \\
\text { extrusive basalts } \\
\text { (Cores 53-54) }\end{array}$ & $\begin{array}{l}\text { (1) Age data K/Ar on the differentiated rocks } \\
\text { (may be unreliable). } \\
\text { (2) Cores } 47-42 \text { Paleocene lignites, Core } 37 \\
\text { (Paleocene) nannofossils ( } 58 \text { m.y.) indi } \\
\text { cates inner shelf, Core } 35 \text { (lower Eocene) } \\
\text { glauconite disappears and foraminifera } \\
\text { show shelf and oceanic facies ( } 53-54 \text { m.y.), } \\
\text { and Core } 34 \text { definitely oceanic facies. } \\
\text { (3) Continuously cored section with good } \\
\text { recovery, found no chert. } \\
\text { (4) More or less continuous calcareous section } \\
\text { with an attenuated section in the lower } \\
\text { Oligocene. } \\
\text { (5) Very high foram content earliest Pliocene } \\
\text { to Quaternary. }\end{array}$ \\
\hline
\end{tabular}


(6) Between Cores 42 and 41 detrital feldspars change compositionally from $\mathrm{K}$-rich to plagioclase.

(7) Cores 38 and 39 abundant diatoms.

(1) Oldest sediments are probably slightly older than those at 214 .

(2) Iron-rich clay nannofossil ooze above basement.

(3) Core 9 sec. 3 is lower Eocene, Core 8 is upper Miocene (Radiolaria), cf. Site 213.

(4) Transition from calcareous to noncalcareous sediments within the lower Eocene.

(5) Distal sediments of Bengal Fan found in Cores 8 and 6 (upper Miocene).

(6) No obvious ash beds. Diatoms more abundant than Radiolaria in upper Miocene to Quaternary sediments.

(7) Spectacular match to 213 .

\begin{tabular}{|c|c|c|c|c|}
\hline $216 \quad 1^{\circ} 27.73^{\prime} \mathrm{N}$ & $90^{\circ} 12.48^{\prime} \mathrm{E}$ & 2247 & $\begin{array}{l}65-67 \\
\text { (Cores } 23 \\
\text { to } 35 \text { ) }\end{array}$ & $\begin{array}{l}<67 \\
\text { (Core 24) }\end{array}$ \\
\hline
\end{tabular}

2.9

64.4
Tuffs above an extrusive basalt of oceanic island type

(1) $\mathrm{K} /$ Ar age on Core 37 on the extrusive basalt. Also dated the nannofossils above the extrusive basalt. These nannofossils latest Cretaceous. May be good maximum K/Ar date for Cretaceous/Tertiary boundary.

(2) Magnetic anomalies to the west maybe 31-71 m.y. from Hiertzler et al., 1968, 66 m.y. from Sclater et al. 1973.

(3) No lignites found. Cores 35-25 nannofossils indicate inner shelf, Core 25 is upper Maastrichtian. Glauconite disappears in Core 23 at Cretaceous/Tertiary boundary, gap record missing. Core 22 lower Paleocene nannofossils and foraminifera show deep-water facies.

(4) Chert found in Core 23 (lower Paleocene), Core 21 (mid-late Paleocene), also Core 18 early middle Eocene.

(5) More or less continuous calcareous section, attenuated section in the lower Oligocene.

(6) Ash beds in late Miocene and younger sediments, with foraminifera more abundant in Pliocene and younger sediments.

(7) In Cores 30-32 found diatoms and sponge spicules.

(1) Oldest sediments are Campanian overlying a dolomite chert sequence.

(2) Oysters and Inoceramus (Cores 30-20), mud crack in 217 A (Core 17), glauconite (217A Core 17, 217 Core 33), and absence of deepwater foraminifera and nannofossils all indicate shallow water origin for the lower sections (Cores 36-30).

(3) Glauconite dies out in Core 33 (late Campan ian). Nannofossils and foraminifera in Cores 25-33 show a definite transition to deep-water facies (middle Maastrichtian).

$\begin{array}{ll}72-80 & 72-80 \\ \text { (Core 36) } & \text { (Core 36) }\end{array}$




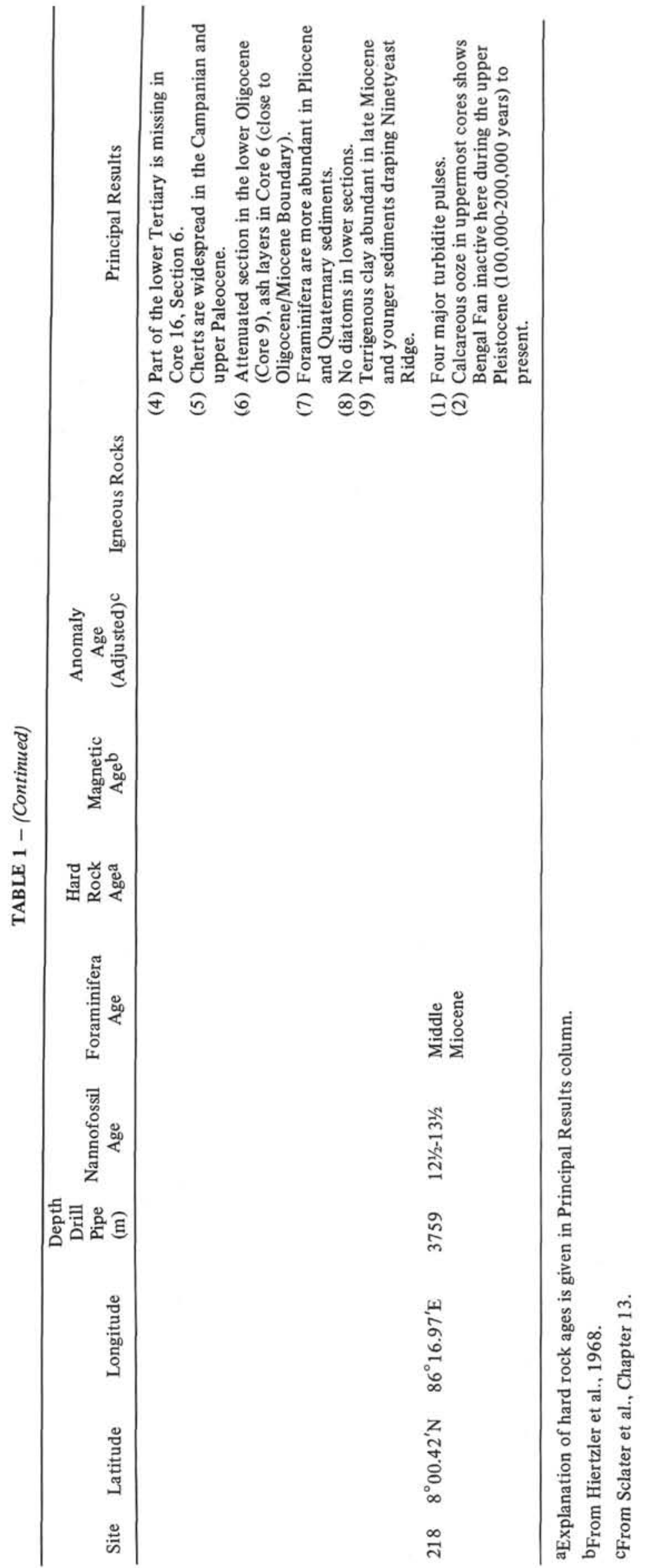

appearance of discrete ash beds. The appearance of the ash beds is considered strong evidence for proximity to the Indonesian volcanoes in the late Pliocene; thus the termination of turbidites could be due to the formation of the pre-trench topographic high by viscoelastic buckling (Hanks, 1971; Wolcott, 1970) as the Wharton Basin plate approached the Sunda Trench. However, alternative explanations such as the migration of turbidite activity in the Bengal Fan or the damming of the gap between the Ninetyeast Ridge and the Sunda Trench in the upper Pliocene are more plausible. More detailed topographic surveys and cores are needed in order to select the most likely explanation.

The basement at Site 211 consists of a diabase sill and basalt which are unlike any other mid-ocean ridge-type rocks (Hekinian, Chapter 17). The sill is dated at 72 m.y.B.P. (McDougall, Chapter 12) and thus cannot be related to recent volcanism. A pronounced topographic hill occurs just south of the site, and other shallow areas are in the general vicinity. The basalts, therefore, may be related to the northeast-trending Cocos-Keeling-Christmas Island complex, the origin of which is unknown.

\section{SITES IN THE VICINITY OF THE NINETYEAST RIDGE}

Three sites $(213,214,215)$ were drilled to the east of, on, and to the west of the Ninetyeast Ridge, respectively, at roughly the same latitude. These sites permit comparison of basement ages and geologic history in the basins on either side of the ridge to that on the crest. Two additional holes $(216,217)$ were drilled further north on the Ninetyeast Ridge to investigate the history of development of this feature.

We obtained excellent sediment basement contacts at the first three sites. Site 213 yielded a basement age of 56-58 m.y.B.P., Site 214 an age of the oldest sediment of 57-61 m.y.B.P., and Site 215 an age of 59-60 m.y.B.P. The relative youth of the site to the west of the ridge was a surprise. McKenzie and Sclater (1971) had suggested, on the basis of some magnetic anomalies to the west, that this portion of oceanic crust was older than anomaly 31 (65 m.y.B.P.). However, Sclater and Fisher (Fig. 6c, in press) have reexamined the tentative correlations of McKenzie and Sclater (1971) in light of the magnetic profile obtained from the D/V Glomar Challenger. They find no basis for the eastward extension of the magnetic anomalies recognized by McKenzie and Sclater (1971) and place a fracture zone at $86^{\circ} \mathrm{E}$ between these anomalies and the Ninetyeast Ridge. Considerable emphasis will be placed on the implications of this site for tectonic reconstructions and the evolution of the Ninetyeast Ridge in a later section.

A second and equally surprising discovery was the close lithostratigraphic similarity between Sites 213 and 215 . Both sites lie on crust which predates the termination of relative motion on the Ninetyeast Ridge fracture zone. A simple reconstruction of the relative position of the sites around the Ninetyeast Ridge during the early Eocene (anomaly 22) shows that Sites 213 and 215 were at the same latitude; however, they were on either side of the Ninetyeast Ridge and were on opposite sides of the active spreading center (Figure 5). Site 215 was north of the 


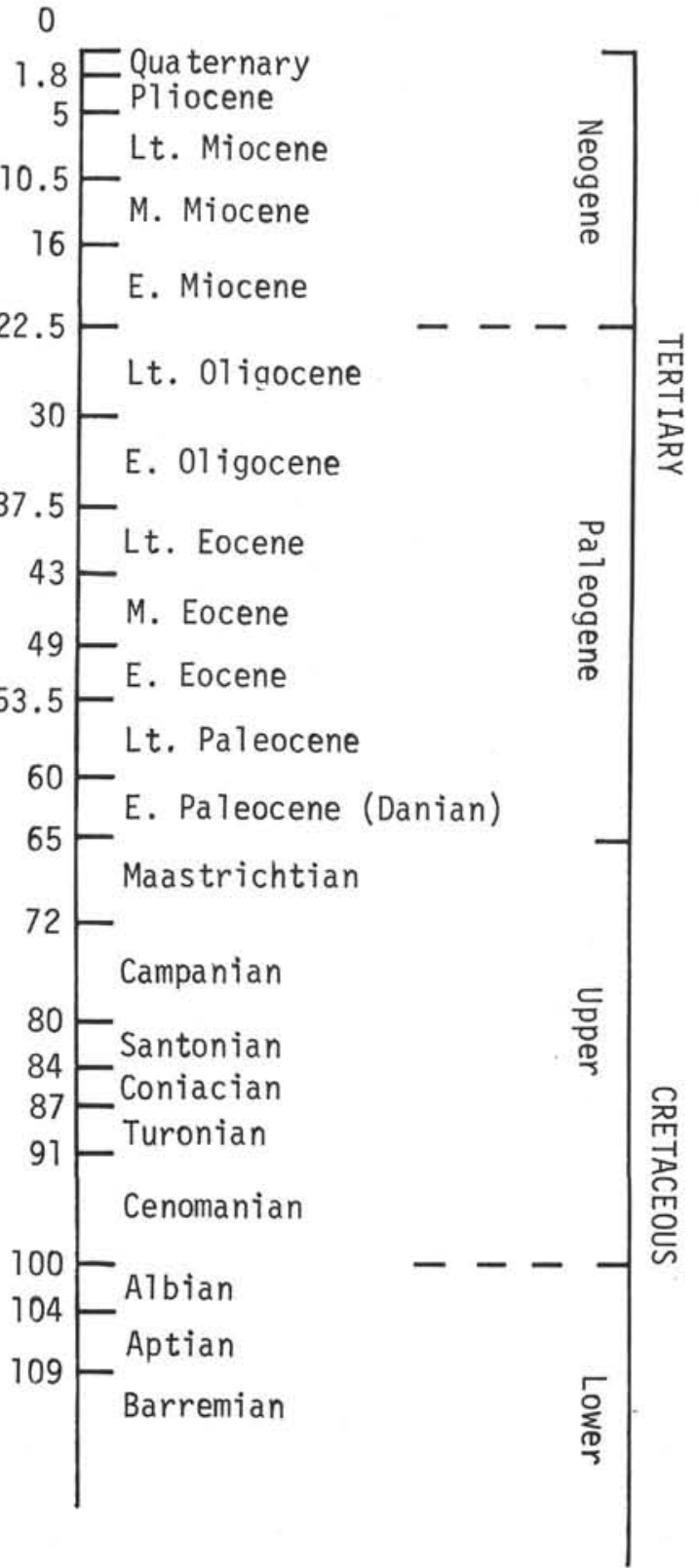

Figure 4a. Time scale used in this chapter for pre-Tertiary nannofossils and foraminifera (after Pimm and Hayes, 1972).

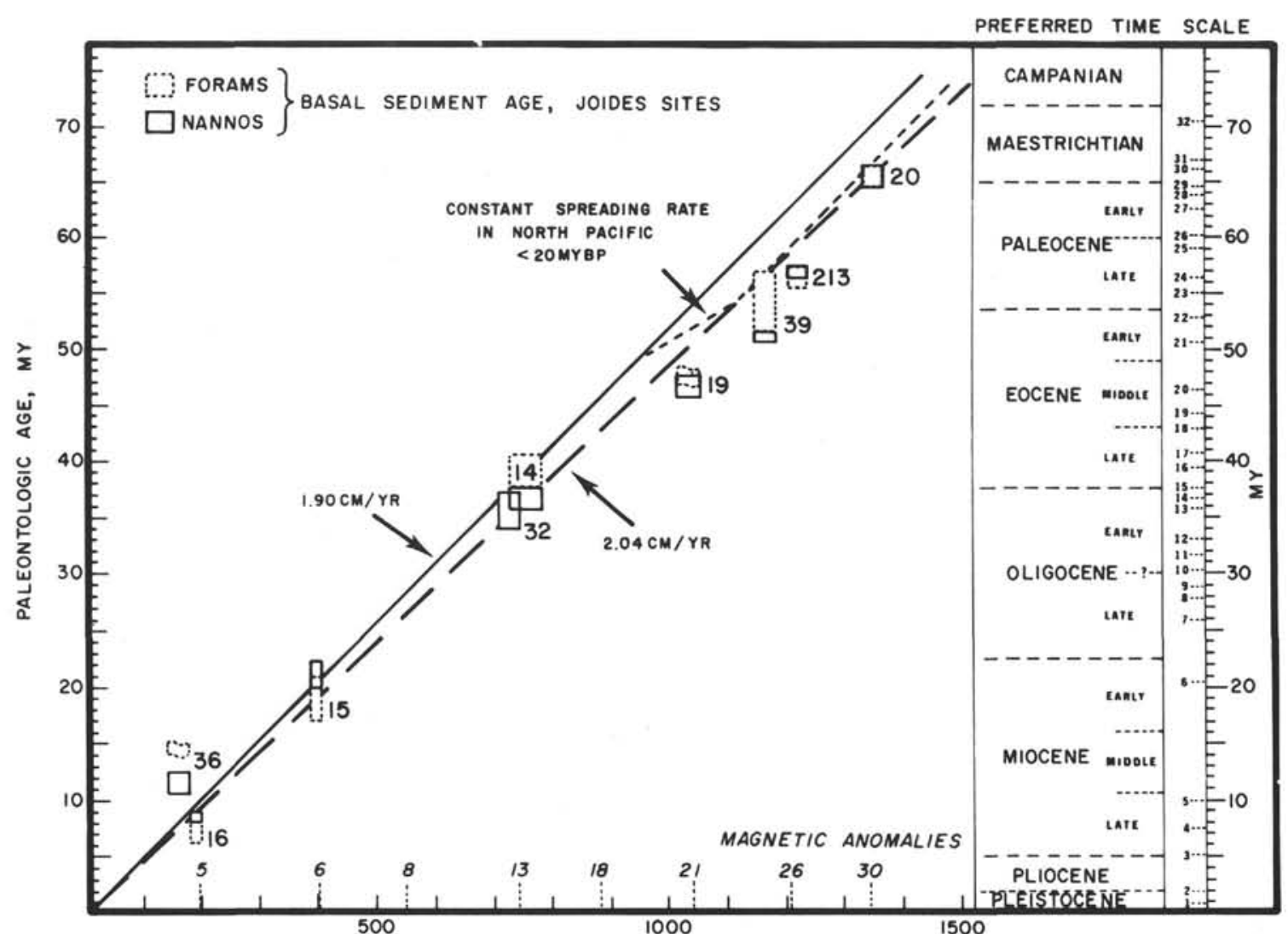

DISTANCE FROM MID-ATLANTIC RIDGE IN KM ALONG V-20 PROFILE (HEIRTZLER ET AL., 1968)

Figure $4 \mathrm{~b}$. Time scale used in this chapter for the magnetic anomalies (cf. Sclater et al., Chapter 13). 


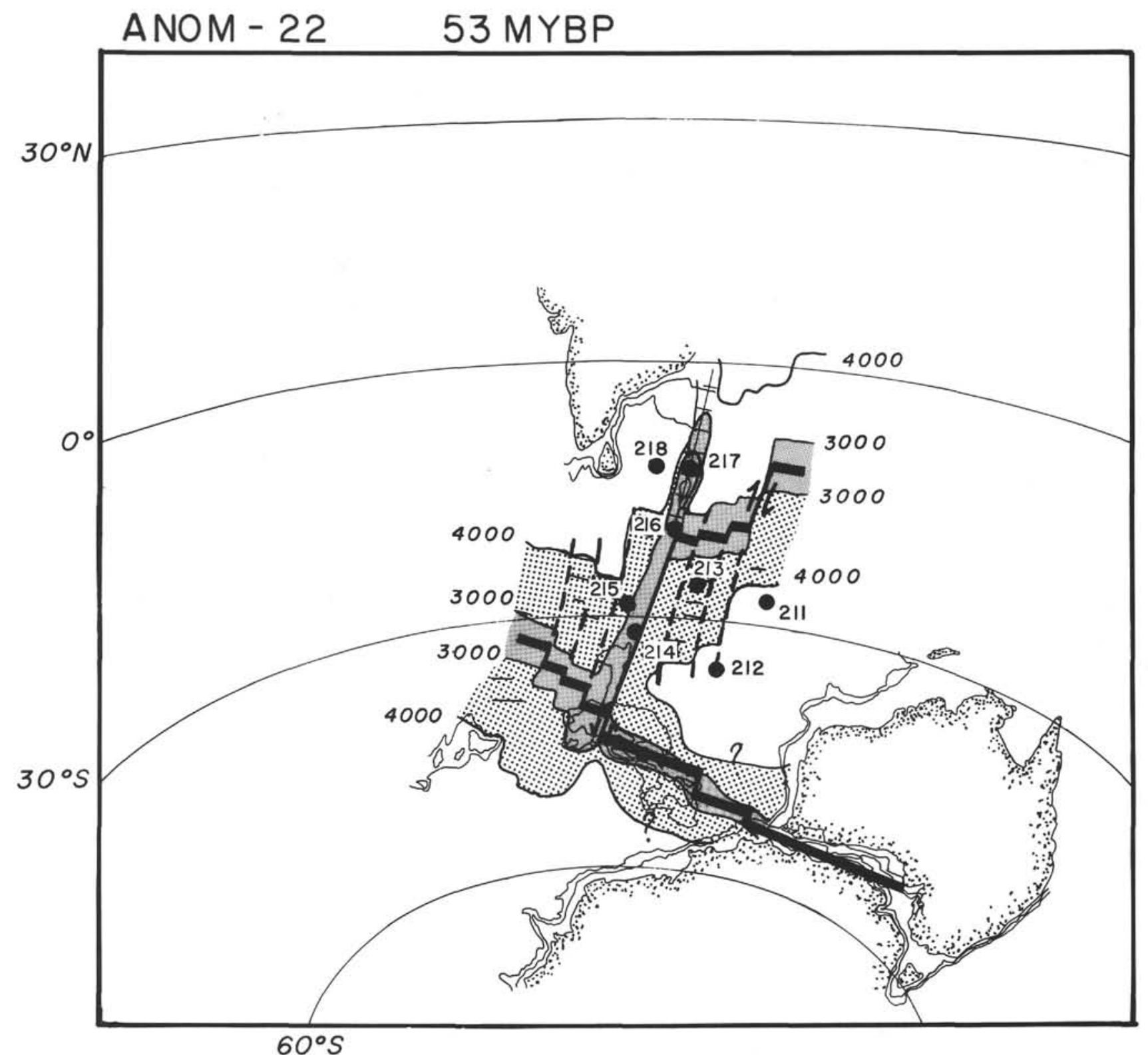

Figure 5. JOIDES deep-sea drilling results superimposed upon a sketch of the paleobathymetry of the eastern Indian Ocean, at the time of anomaly 22, 53 m.y.B.P. The contours were determined using the depth/age relationship of Sclater et al., 1971.

southeast Indian Ridge, and Site $213^{\circ}$ was south of the active spreading center in the Wharton Basin. At this time, Australia had not yet separated from Antarctica. Sclater and Fisher (in press) have shown that the observed rate of spreading either side of the Ninetyeast Ridge in the Eocene was $8 \mathrm{~cm} / \mathrm{yr}$. Sites 213 and 215 were formed 6 and 9 m.y., respectively, before the middle Eocene (anomaly 20 or 50 m.y.B.P.). Thus, at the time of its formation Site 213 was $1000 \mathrm{~km}(2 \times 8 \mathrm{~cm} / \mathrm{yr}$ for 6 m.y. $)$ north of Site 215 . In light of these facts the close correspondence of the lithostratigraphy in the lowermost sections is surprising. By the Oligocene, motion along the Ninetyeast Ridge had terminated and the two plates were welded together and moved north as a unit. This accounts for the similar transition from brown clay to siliceous ooze in the upper sections in both holes.

The sites on the crest of the Ninetyeast Ridge present evidence for a subaerial (214) and shelf $(214,216,217)$ environment early in their history with subsequent sinking to oceanic depths. For example, at Site 214 glauconitic carbonate silt and sand with shelf affinities occurs above Paleocene lignites, tuffs, and tuffaceous sediments (Figure 3, Table 1). At Site 217 the basal section consists of a late Maastrichtian to early Campanian shelly micrite grading downwards to a dolomitized reef facies interbedded with cherts. Site 216 contains a basal section of late Mastrichtian age composed of glauconitic sediments of a shallow shelf environment. The ages of the basal sections of 
all three sites increase to the north. In addition, the age of onset of deep water facies also increases in the same direction.

The Ninetyeast Ridge runs almost straight along a line $5^{\circ}$ east of north from Broken Ridge at $31^{\circ} \mathrm{S}$ to about $8^{\circ} \mathrm{S}$. The ridge has a cross-section in the form of an asymmetrical bell, with the steepest slope and a deep trough to the east. North of $8^{\circ} \mathrm{S}$ the ridge changes character to become a series of en echelon northeast-southwest-trending blocks running due north, terminating beneath the Bengal Fan at $12^{\circ} \mathrm{N}$. To the east of the ridge lies a series of long, linear north-south-trending deeps and highs. The most prominent trough lies immediately east of the ridge and Sclater and Fisher (in press) have suggested that it marks the remnant of the old transform fault. These authors and Bowin (1973) have further suggested that the ridge, which is to the west of the deep, is an extrusive feature attached to the Indian plate. Data from our three drill holes strongly support this hypothesis. First, the age of the basement increases to the north. This is similar to the direction of increasing age of the Indian plate. Second, the depth of basement at Sites 214,216 , and 217 increases to the north. This is similar to the direction of increasing depth on the Indian plate. Finally late Cretaceous biofacies changes at Hole 217 are evidence for a rapid northward movement of this site during the Maastrichtian (Chapter 40). Such a rapid movement $\left(10^{\circ}\right.$ north in less than 10 m.y. $)$ is predicted for the Indian plate during this time span from the magnetic anomaly identifications. Finally the basal sediment ages for Sites 214 and 216 on the Ninetyeast Ridge are very close to the basement ages predicted for the oceanic crust immediately to the west. Site 215 is west of 214 and has a slightly older age. Sclater and Fisher have tentatively identified magnetic anomaly 31 (66 m.y.B.P. early Maastrichtian) on the Challenger profile just west of Site 216.

\section{BENGAL FAN SEDIMENTS}

The Bengal Fan is almost $3000 \mathrm{~km}$ long and over 1000 $\mathrm{km}$ wide and has a sediment thickness at some points that exceeds $12 \mathrm{~km}$ (Curray and Moore, 1971). Turbidity currents have transported the sediments from the Ganges-Brahamaputra River delta through the Swatch of No Ground and into an extensive criss-crossing net of meandering fan valleys in the Bengal and Nicobar fans (cf. Fig. 1 of Curray and Moore, 1971). At four sites $(211,215$, 217 , and 218) we penetrated sediments whose source area was probably the Ganges-Brahamaputra River (Pimm, Chapter 39). At Hole 211 (Figure 3) we drilled through large sections of clayey silt and silty sand of Pliocene age. These terrigenous sediments are related mineralogically to those at Hole 218 (Thompson, Chapter 38) and have clearly come from the Ganges-Brahamaputra River. Presumably they reached Site 211 by passing through the gap between the Ninetyeast Ridge and the Nicobar Islands (see Fig. 1 of Curray and Moore, 1971) and passing north of the Investigator Fracture Zone (Figure 1).

In the Miocene sediments of Site 215 terrigenous clays from the distal portions of the Bengal Fan were recognized. Absence of turbidites here in the Pliocene and Quaternary may imply maximum fan progradation during the Miocene or may simply reflect a change on the complex fan structure to the north that diverted post-Miocene turbidites to other areas. The Quaternary to late Miocene pelagic calcareous sediments at Site 217 contain a considerable admixture of terrigenous clay. The drilling results imply gradual sinking of the Ninetyeast Ridge as well as northward migration toward the source of terrigenous material. Both factors enhance the possibility of increased clay deposition either from the dilute suspensions of turbidity currents or even from suspension in surface waters. Sediment input into the Bay of Bengal presumably increases in the Pliocene and Quaternary as a result of both uplift of the Himalayas and sea level lowering due to glaciation. Our drilling results yield no evidence for recent uplift on the Ninetyeast Ridge, and the clays in Site 217 are more than 200 meters above the nearby Nicobar Fan. Thus, these clays probably represent the slow deposition of the finer fraction which remained in suspension in the bottom water some 100 to 300 meters above the denser fraction of the turbidite flow.

The Quaternary to middle Miocene sediments at Site 218 are nearly all turbidite deposits from the Bengal Fan. Observed fluctuations of the sand-silt-clay ratios down the hole and occasional interbedded calcareous oozes may simply reflect changing proximity of the site to submarine channels in the fan system, or they may be related to tectonic activity in the Himalayan hinterland. More and deeper drill holes are needed to resolve between these two explanations. Four major pulses of turbidite activity have been recognized (Thompson, Chapter 38; Pimm, Chapter 39). Stratigraphic equivalents to onlapped beds marking the upper unconformity of Curray and Moore (1971) were found to be late Miocene where sampled in 218 (Curray and Moore, Chapter 16). These strata lie near the base of a section of silt and silty sand (pulse 2 of the series) which could reflect orogeny in the Himalayas coeval to that forming the mid-fan upper unconformity. The gross age difference between predicted (Plio-Pleistocene) and actual (Miocene) age at about 450-500 meters implies much greater early Tertiary deposition on the fan than had been suggested by Curray and Moore (1971).

\section{TECTONIC HISTORY OF THE EASTERN INDIAN OCEAN}

The deep-sea drilling results from Leg 22 add three important facts to the interpretation of the magnetic, topographic, and gravity data (Figure 1). First, they confirm the identification of the magnetic anomalies in the Wharton Basin and permit the construction of an early Tertiary magnetic time scale which agrees better with the biostratigraphic scale of Berggren (1972) than the original time scale of Heirtzler et al. (1968). Second, Site 215 gives a much younger age for the oceanic crust just to the west of the Ninetyeast Ridge than the magnetic lineations between $83^{\circ} \mathrm{E}$ and $86^{\circ} \mathrm{E}$. This new fracture zone at $86^{\circ} \mathrm{E}$ offsets Paleocene crust (anomaly 26, 60 m.y.B.P.) left laterally $8^{\circ}$ to the north. Finally, the holes of the Ninetyeast Ridge have the same age as the crust to the west. This and other evidence mentioned previously show that the ridge is attached to the Indian plate. 
These last two facts have major implications for the tectonic history of the eastern Indian Ocean and the mode of formation of the Ninetyeast Ridge. The fracture zone at $86^{\circ} \mathrm{E}$ offsets Paleocene crust left laterally $8^{\circ}$. However, at the axis of the southeast Indian Ridge, the same fracture zone (Figure 1) has a $3^{\circ}$ right lateral offset. Hence, between the Paleocene and the present some $11^{\circ}$ of excess oceanic crust has been created between $8^{\circ} \mathrm{S}$ and $40^{\circ} \mathrm{S}$ just west of the Ninetyeast Ridge. This is best explained by assuming that between the Paleocene and the present the active spreading center west of the Ninetyeast Ridge jumped progressively southward to its present position. Though the exact time of the jump (or jumps) is unknown, it probably occurred before the commencement of separation of Antarctica and Australia in the Eocene (anomaly 22 from Weissel and Hayes, 1972).

The Ninetyeast Ridge is probably of extrusive origin and is attached to the Indian plate. Hekinian (Chapter 17) suggests that hard rock data from the ridge show a marked affinity to those from other oceanic islands such as Amsterdam and St. Paul islands, which lie southwest of the southern end of the Ninetyeast Ridge. Closure about the pole of Weissel and Hayes (1972) places the southeastern tip of these islands at the base of the Ninetyeast Ridge in the Oligocene (anomaly 11 or 32 m.y.B.P.). The hard rock affinity and the reconstructed position of the islands are suggestive of a tectonic relationship between them and the Ninetyeast Ridge.

The simplest assumption regarding the origin of the Ninetyeast Ridge is that it was formed by the migration of the Indian plate along an old active transform fault over an isolated magma chamber. This is similar to the hot spot concept of Morgan (1971) with a hot mantle plume material rising from the aesthenosphere. As a consequence, magma was preferentially deposited on the Indian plate at the junction of the southeast Indian Ridge and the old transform fault. In such a model, the Ninetyeast Ridge should show the same increase in age with distance as the crust on the Indian plate. To investigate this problem the age of the sites on and to the west of the Ninetyeast Ridge and the age of the oceanic crust just west of the ridge and also to the west of the $86^{\circ} \mathrm{E}$ fracture was projected onto a north-south section of the ridge (Figure 6). The older two sites (216 and 217) and possibly as far south as $8^{\circ} \mathrm{N}$ show the same age versus distance relationship as the crust between $83^{\circ} \mathrm{E}$ and $86^{\circ} \mathrm{E}$. Thus this older, en echelon section is compatible with a simple isolated magma chamber source for the excess basaltic material. However, the distance between Sites 253 (Leg 26) and 216 is $12^{\circ}$ greater than the distance separating anomalies 30 and 18 between $83^{\circ} \mathrm{E}$ and $86^{\circ} \mathrm{E}$. The sites cover exactly the same time span (Latest Cretaceous to early Eocene) as the anomalies. Thus the Ninetyeast Ridge in this section between at least $1^{\circ} \mathrm{N}$ and $25^{\circ} \mathrm{S}$ cannot have been formed by a constant rate of migration between the Late Cretaceous and early Eocene of the Indian plate over an isolated magma source.

Evidence has been presented that the Ninetyeast Ridge is attached to the oceanic crust immediately to the west. Also it has been suggested that between anomalies 27 and 20 (Paleocene to middle Eocene) the oceanic spreading center west of the Ninetyeast Ridge jumped $11^{\circ}$ south. Thus, a possible explanation of the ages on the Ninetyeast Ridge is that this jump occurred at the time of anomaly 27 and that the long straight section from $10^{\circ} \mathrm{S}$ to $20^{\circ} \mathrm{S}$ is due to a leak in the transform fault as the ridge jumped south. This model (Figure 7) predicts that between $10^{\circ} \mathrm{S}$ and $21^{\circ} \mathrm{S}$ the Ninetyeast Ridge is almost exactly the same age, but that south of $21^{\circ} \mathrm{S}$ it decreases in age in the same manner as the crust immediately to the west. If this model is correct, then the Ninetyeast Ridge is related directly to the junction of the southeast Indian Ridge and an old transform fault. As the growth of Ninetyeast Ridge appears to follow the jump southward of the spreading center, the extrusion process was related to forces in the lithospheric plate (leaky transform fault) and not to a magma chamber beneath the actual plate.

For a fixed mantle frame hot spot origin for the Ninetyeast Ridge, the major problem is the separation between Sites 253 (Leg 26) and 216 which is twice that between anomalies 19 and 30 west of the fracture zone at $86^{\circ} \mathrm{E}$. This difference can still be accounted for by postulating an isolated magma chamber beneath the Indian plate. In this model the Indian plate would move north relative to the fixed magma chamber at half the total spreading rate prior to 60 m.y.B.P. and past 50 m.y.B.P. But between this time span, the rate would increase to the total spreading rate on the southeast Indian spreading center. The jump southward at 60 m.y.B.P. would prevent the active spreading center from getting north of the mantle source (Figure 8).

Presently available data do not allow us to choose between the two models. However, we have a definite preference for the first as the ages on the Ninetyeast Ridge are accounted for by a localized phenomenon. In the second model, a rapid increase in rate of motion of the Indian plate relative to a fixed mantle frame would affect the Antarctic plate and hence the Pacific plate. No such disturbances in spreading rate of "hot spot" activity are reported for the Pacific Ocean in the Paleocene (50-60 m.y.B.P.).

\section{RECONSTRUCTIONS}

On the basis of magnetic and topographic information from the eastern Indian Ocean and the Deep Sea Drilling results, Sclater and Fisher (in press) have reconstructed the relative positions of the Indian, Antarctic, and Australian continents from the Late Cretaceous until the present (Figure 9). For the sake of completeness, a brief summary of this reconstruction is included in this chapter.

Excellent paleomagnetic data exist for Australia spanning the Tertiary and Late Cretaceous. After closing the continents towards a fixed Australia using the sea-floor data, Sclater and Fisher (in press) determined the paleolatitude by rotating them all about the equatorial pole that fitted the virtual geomagnetic pole of Australia to the south pole.

In the Early Cretaceous, India, Antarctica, and Australia formed the eastern part of the Gondwana land mass in the position first suggested by DuToit (1937). Around 100-105 m.y.B.P. a spreading center trending slightly south of east with transform faults trending just east of north became 


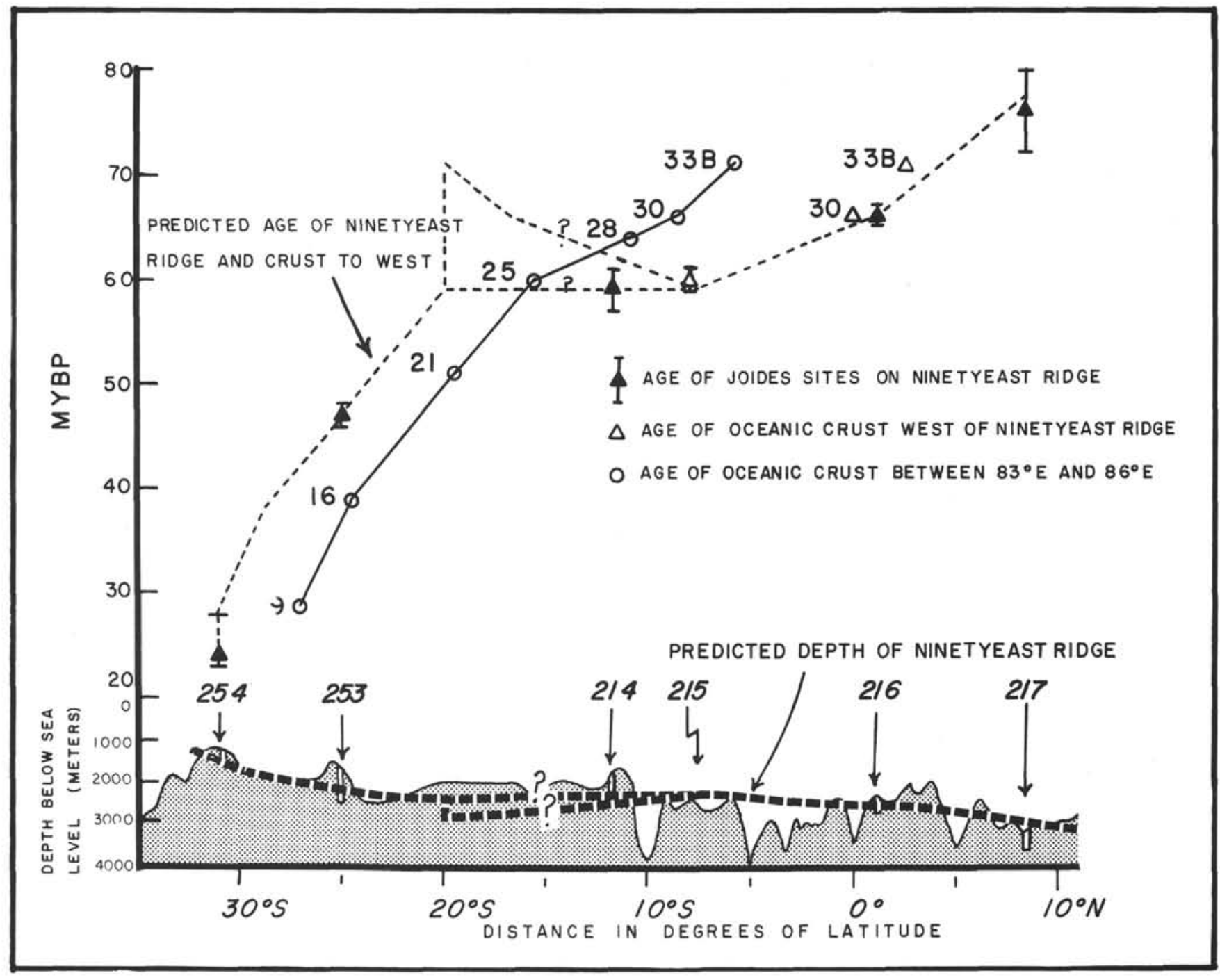

Figure 6. Comparison of depth and age versus distance for the Ninetyeast Ridge, the crust between the ridge and $86^{\circ} E$, and the crust between $83^{\circ}$ and $86^{\circ} \mathrm{E}$.

active in the Central Indian and Wharton basins, and for the next 20 m.y.B.P. India moved north-northeasterly with respect to Antarctica. Close to 80 m.y.B.P. (this time is not exact) there was a change in the direction of relative motion with India separating from the fixed AustraliaAntarctica region in a more northeasterly direction. The pole of relative motion was close to $70^{\circ}$ from the Ninetyeast transform fault (the trough just east of the Ninetyeast Ridge). The southern extension of the Investigator Ridge is the fossil remnant of the offset across a transform fault. Around 64 m.y.B.P. (anomaly 28) the pole of relative motion moved to become almost $90^{\circ}$ from the Ninetyeast transform fault. Between 64 m.y.B.P. (anomaly 28) and 53 m.y.B.P. (anomaly 22) the spreading center just west of the Ninetyeast transform fault jumped $11^{\circ}$ to the south. This jump could have occurred as a series of small steps at different times or in a single movement at one time.

Close to 53 m.y.B.P. Antarctica started to separate from Australia. The Ninetyeast transform fault still marked the relative motion between India and Antarctica. A new plate was formed between India and Australia with an active boundary in the vicinity of the northern section of the Ninetyeast Ridge. As the relative motion between this plate and Australia is unknown, Sclater and Fisher (in press) were unable to compute the relative motion on the plate boundary. It is possible that this plate boundary, which was active between 53 m.y.B.P. and 32 m.y.B.P., could have caused the en echelon faulting on the northern section of the Ninetyeast Ridge. The relative motion either side of the Ninetyeast transform fault terminated 32 m.y.B.P., and India and Australia became part of the same plate. The direction of motion between these two continents and the Antarctic plate changed to northeast southwest. The north-south transform fault joining the southeast Indian Ridge to the Antarctic-Australia Ridge became an S-shaped series of active spreading centers and transform faults with relative motion in a northeasterly-southwesterly direction. This geometry of the active plate boundary continued until the present.

From the reconstructions (Figure 9) it is possible to draw some simple conclusions concerning the relative 

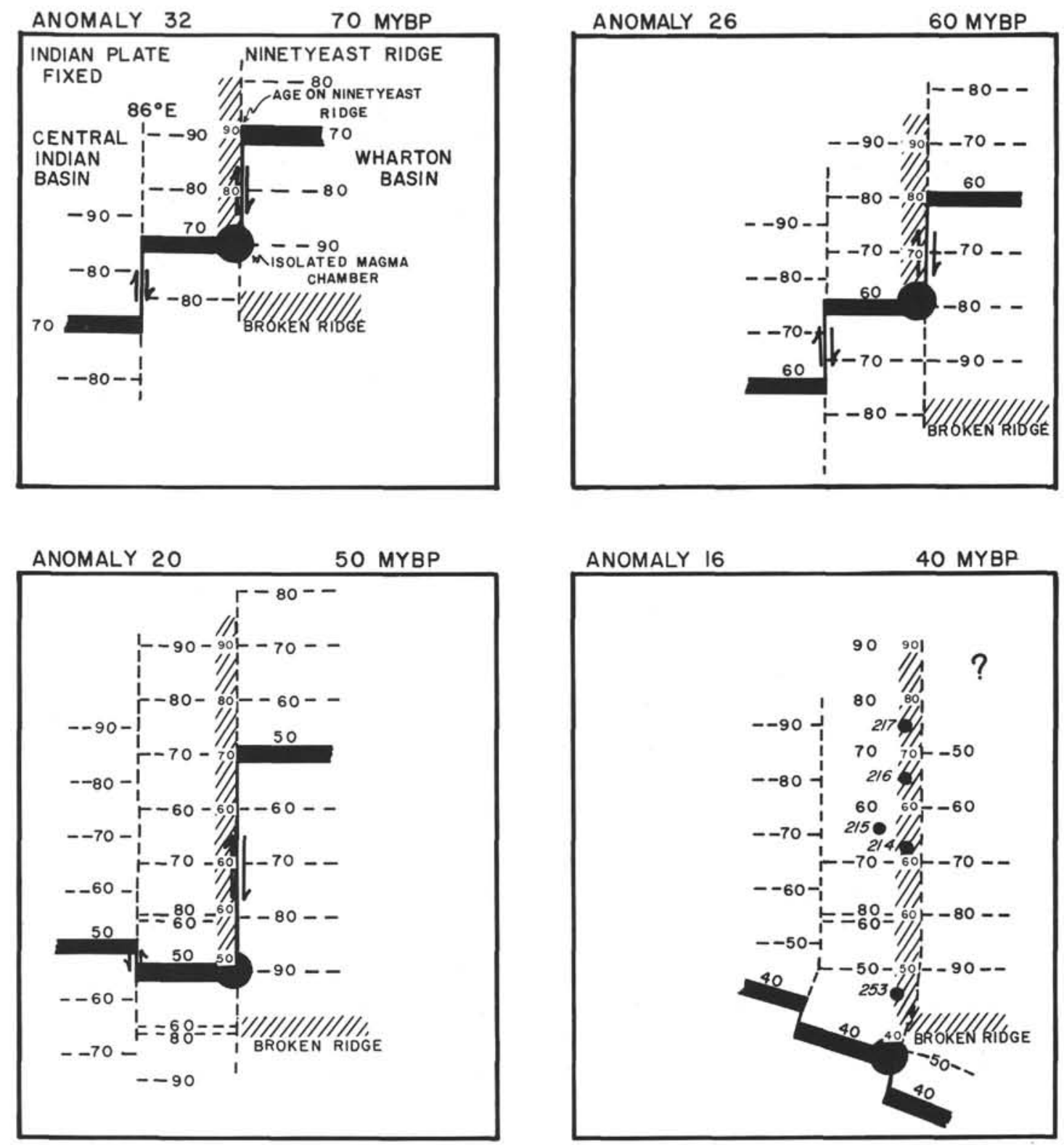

Figure 7. Tectonic model for the Ninetyeast Ridge assuming the magma chamber is attached to the Indian plate and remains at the junction of the active southeast Indian Ridge and the Nintyeast Ridge.

positions and paleolatitude of the various sites at different times in the past. Perhaps the most spectacular history is that of Site 217. The oceanic crust below this site and Site 212 was created when Antarctica and India were very close together during the Late Cretaceous. Between 80 and 53 m.y.B.P. Site 217 appears to have moved north at a rate of nearly $1.5^{\circ}$ of latitude per million years. From 53 to 32 m.y.B.P. (Eocene to Oligocene) this site was almost stationary about $10^{\circ} \mathrm{S}$ of the equator, and during the last 30 million years it has moved north at a rate slighly greater than $0.5^{\circ}$ per million years. It is of interest to note the position of Site 217 relative to Australia. The site was at the same latitude as Canarvan Basin 80 m.y.B.P. (earliest Campanian). By 64 m.y.B.P. (early Paleocene) the site was $5^{\circ} \mathrm{N}$ of the northernmost edge of the Australian continent, and by 53 m.y.B.P. (early Eocene) it was $20^{\circ} \mathrm{N}$ of the Australian continent. The history of Site 216 is similar to that of Site 217 except that the oceanic crust was created at a later time and hence moved northward slower during the earliest stages of its history. Also Site 216 probably did not reach tropical waters until the early Miocene. It is also of interest to note that by 64 m.y.B.P. Site 212 was at the latitude at which Site 216 was created and that at this time Site 211 had the same latitude as Site 217. Concerning the three sites traversing the Ninetyeast Ridge, Site 213 was originally formed north of Sites 214 and 215. After formation, Site 213 moved south relative to the other two which remained almost stationary in latitude until 32 

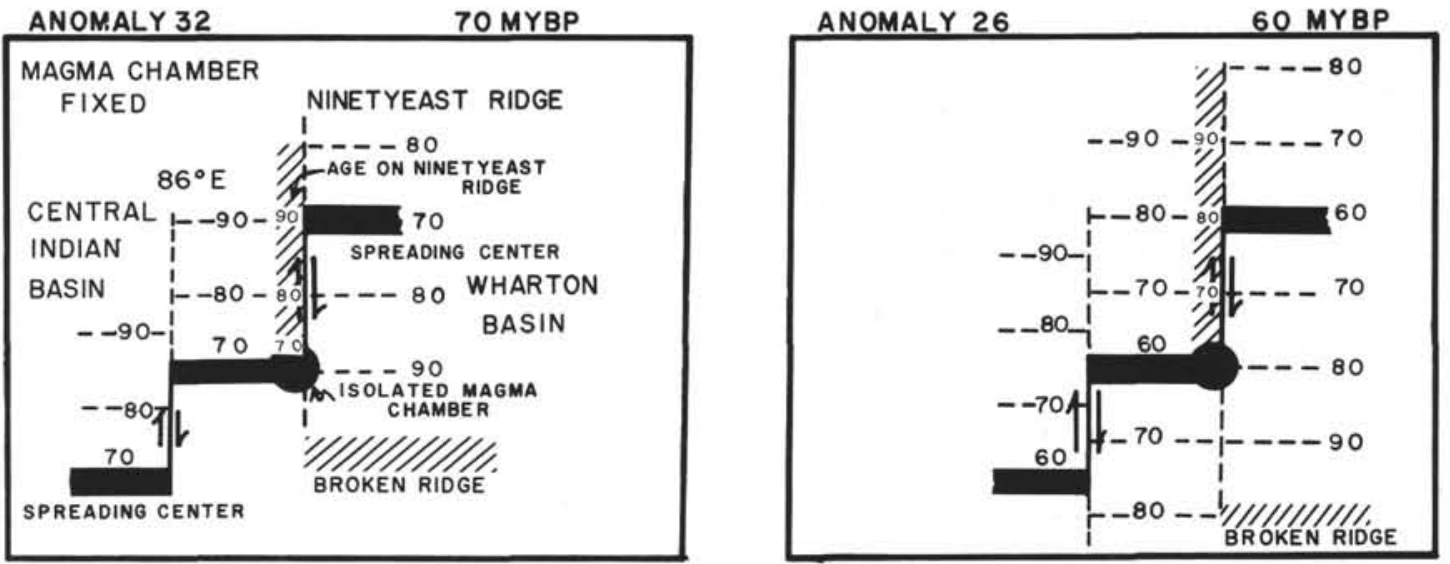

ANOMALY 20

50 MYBP
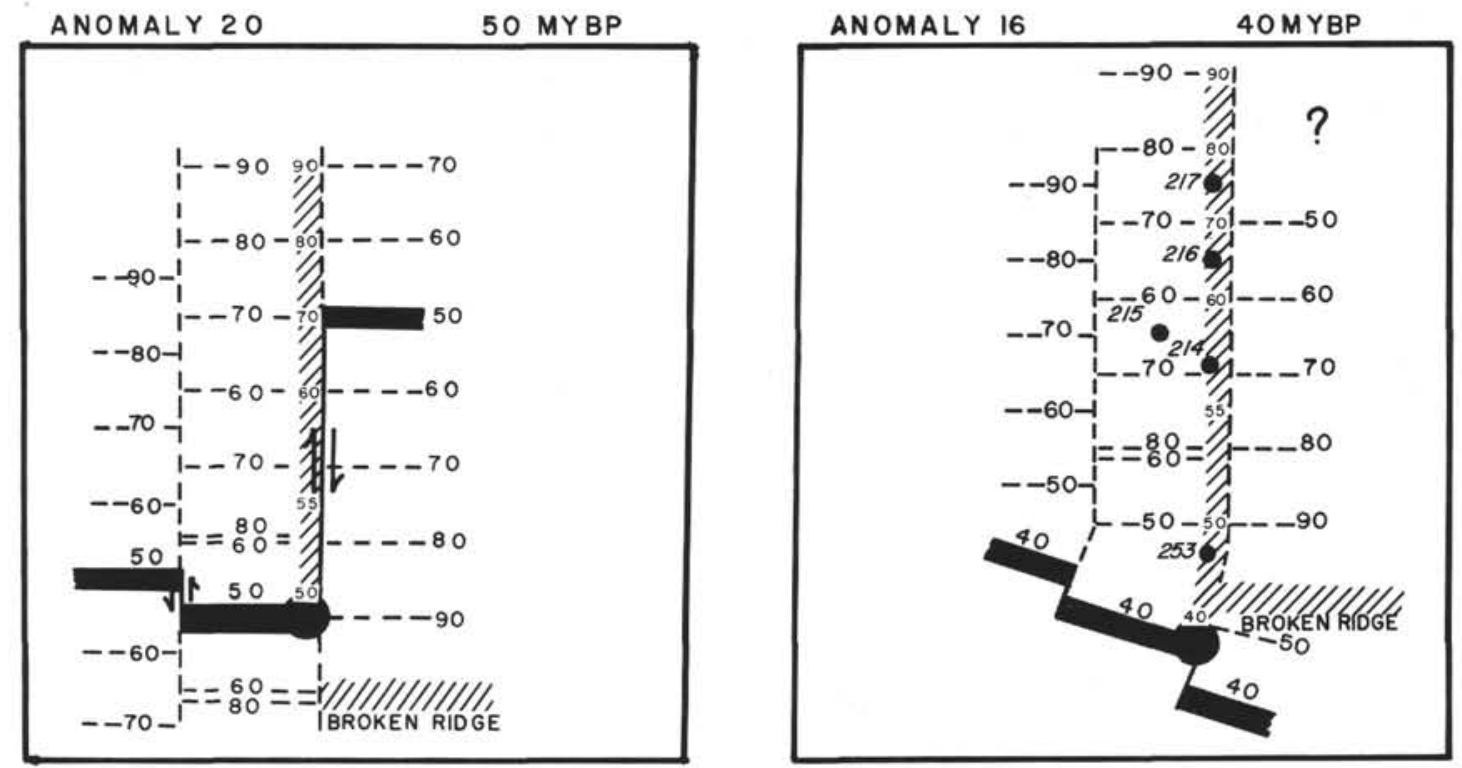

Figure 8. Tectonic model for the Ninetyeast Ridge assuming a fixed mantle source for the magma chamber (hot spot). The Indian plate moves north relative to the magma chamber.

m.y.B.P. (Oligocene). At this time they became fused at the same latitude $30^{\circ} \mathrm{S}$ and moved northwards together at roughly $0.5^{\circ}$ per million years.

If these reconstructions are valid, two further conclusions can be drawn from them. First, for some unspecified length of time, between the early Eocene (53 m.y.B.P.) and the middle Oligocene (32 m.y.B.P.), Sites 211, 212, and 213 in the Wharton Basin were bounded to the north and south by mid-ocean ridges associated with two active spreading centers. Second, prior to the Eocene and the separation of Australia from Antarctica, it is obvious that both the shallow and deep water circulation patterns around these continents would be controlled by the early history of Broken Ridge and Kerguelen Plateau.

\section{ACKNOWLEDGMENTS}

We would like to thank the operations manager, Lamar Hayes; Captain Dill and the crew and engineers; and Cotton Guess and the drillers for our successes on this cruise. We would like to express our particular gratitude to the Deep
Sea Drilling Project marine technicians for their selfless hours of toil during and after the cruise. The senior author would like to thank ONR for support in writing this chapter.

\section{REFERENCES}

Anon, 1964. Russian Chart of the Indian Ocean $1: 15,000,000$. Committee of Management for geodesy and cartography of the Soviet Ministry of the U.S.S.R. Moscow.

Berggren, W. H., 1972. A Cenozoic time scale-some implications for regional geology and paleobiogeography: Lethaia, v. 5, p. 195-215.

Bowin, C., 1973. Origin of Ninetyeast Ridge from studies near the equator (Abstract): Am. Geophys. Union Trans., v. 54, p. 330.

Curray, J. R. and Moore, D. G., 1971. Growth of the Bengal deep-sea fan and denudation of the Himalayas: Geol. Soc. Am. Bull., v. 82, p. 563-572.

Dietz, R. D. and Holden, J. G., 1971. Pre-Mesozoic oceanic crust in the eastern Indian Ocean (Wharton Basin): Nature, v. 229, p. 307-312. 

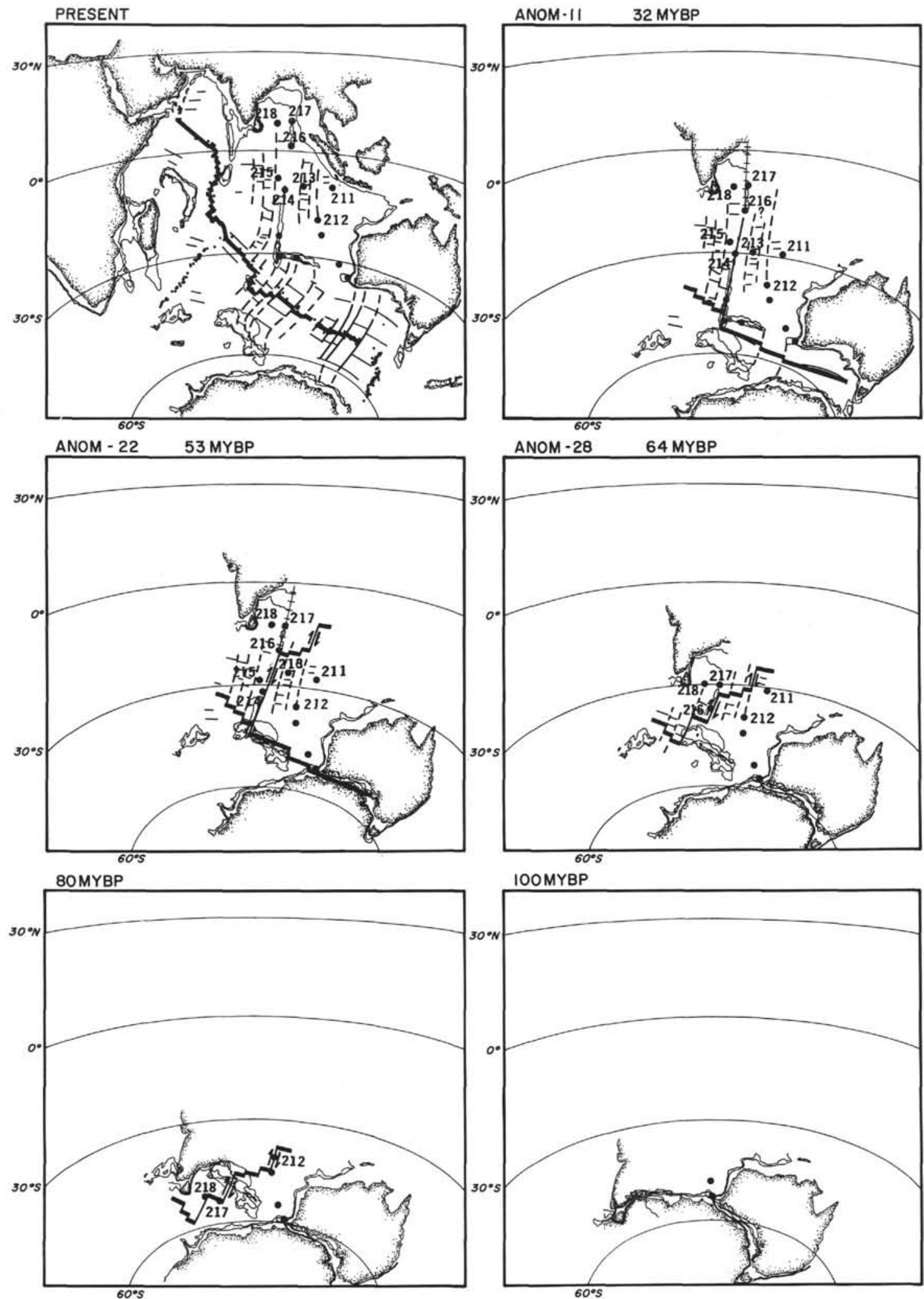

Figure 9. Reconstruction of the relative position of India, Australia, and Antarctica, 32 m.y.B.P., 53 m.y.B.P., 64 m.y.B.P., 80 m.y.B.P., and 100 m.y.B.P. The heavy lines mark the active spreading centers. The thin continuous lines are known fracture zones; the dashed lines projected fracture zones. The horizontal lines represent identified magnetic anomalies (see Figure 2 for numbers). The JOIDES sites from Leg 22 are numbered (after Sclater and Fisher, in press). 
DuToit, A. L., 1937. Our wandering continents: Edinburgh and London (Oliver and Boyd).

Ewing, M., Eittreim, S., Trucham, M., and Ewing, J. I., 1969. Sediment distribution in the Indian Ocean: Deep-Sea Res., v. 16, p. 231.

Falvey, D. A., 1972. Sea floor spreading in the Wharton Basin (northeast Indian Ocean) and the breakup of eastern Gondwanaland: Australian Petrol. Explor. Assoc., v. 12, p. 2.

Fisher, R. L., Engel, C. G., and Hilde, T. W. C., 1970. Basalts dredged from the Amirante Ridge, Western Indian Ocean: Deep-Sea Res., v. 15, p. 521-524.

Fisher, R. L., Sclater, J. G., and McKenzie, D. P., 1971. The evolution of the Central Indian Ridge, Western Indian Ocean: Geol. Soc. Am. Bull., v. 82, p. 553-562.

Francis, T. J. C. and Raitt, R. W., 1967. Seismic refraction measurements in the northwest Indian Ocean: J Geophys. Res., v. 71, p. 427-449.

Hanks, T. C., 1971. Kuril Trench-Hokkaido Rise system: large shallow earthquakes and simple models of deformation: J. Geophys. Roy. Astro. Soc., v. 23, p. 173.

Heezen, B. C. and Tharp, M., 1965. Physiographic diagram of the Indian Ocean, the Red Sea, the South China Sea, the Sulu Sea and the Celebes Sea: New York (Geol. Soc. Am. Inc.).

Heirtzler, J. R., Dickson, G. O., Herron, E. M., Pitman, W. C., and Le Pichon, X., 1968. Marine magnetic anomalies, geomagnetic field reversals, and motions of the ocean floor and continents: J. Geophys. Res., v. 73, p. 2119-2136.

Le Pichon, X. and Heirtzler, J. R., 1968. Magnetic anomalies in the Indian Ocean and sea floor spreading: J. Geophys. Res., v. 73, p. 2109-2117.

LePichon, X. and Talwani, M., 1969. Regional gravity anomalies in the Indian Ocean: Deep-Sea Res., v. 16, p. 263-274.

Matthews, D. H., 1966. The Owen fracture zone and the northern end of the Carlsberg Ridge: Phil. Trans. Roy. Soc, London, Series a, v. 259, p. 172-186.
McKenzie, D. P. and Sclater, J. G., 1971. The evolution of the Indian Ocean since the Late Cretaceous: Geophys. J. Roy. Astro. Soc., v. 25, p. 437-528.

Morgan, J., 1971. Plate motion and deep mantle convection: Nature, v. 23, p. 42-43.

Pimm, A. C. and Hayes, D. E., 1972. General Synthesis. In Hayes, D. E., Pimm, A. C., et al. Initial Reports of the Deep Sea Drilling Project, Volume XIV: Washington (U. S. Government Printing Office), p. 955-975.

Scientific Staff, Leg 26, Joides Deep Sea Drilling Project, 1973. Across the southern Indian Ocean aboard Glomar Challenger: Geotimes, v. 18, n. 3, p. 16-19.

Sclater, J. G. and Fisher, R. L., in press. The evolution of the east central Indian Ocean with emphasis on the tectonic setting of the Ninetyeast Ridge. Geol. Soc. Am. Bull.

Sewell, S. R. B., 1925. Part 1, The geography of the Andaman Sea Basin. In Geographic and oceanographic research in Indian waters: Mem. Asiatic Soc. Bengal, v. 9 , p. 1-26.

Smith, A. G. and Hallam, A., 1970. The fit of the southern continents: Nature, v. 225 , p. 139-144.

Stocks, Th., 1960. Zur Bodengestalt des Indischen Oceans: Erdkunde, Anhio Wiss. Geogr., v. 14, p. 161-170.

Vacquier, V. and Taylor, P., 1966. Geothermal and magnetic survey off the coast of Sumatra, Part 1: Tokyo Univ. Earth. Res. Inst. Bull., v. 44, p. 531-540.

Veever, J. J., Jones, J. G., and Talent, J. A., 1971. Indo-Australian stratigraphy and the configuration and dispersal of Gondwanaland: Nature, v. 229, p. 383-388.

Walcott, R. I., 1970. Flexural rigidity, thickness, and viscosity of the lithosphere: J. Geophys. Res., v. 75, p. 3941 .

Weissel, J. K. and Hayes, D. E., 1972. Magnetic anomalies in the southeast Indian Ocean. In Hayes, D. E. (Ed.), Antarctic oceanology II, the Australian-New Zealand section: Washington (Am. Geophys. Union). 